\title{
A new primer set for amplification of ITS-rDNA in Ditylenchus destructor
}

\section{Niloufar Mahmoudi' ${ }^{1,}$, Davoud K. Nejad ${ }^{3}$, Fatemeh Shayanmehr ${ }^{4}$}

\author{
${ }^{1}$ Peoples’ Friendship University of Russia, Moscow, Russian Federation \\ ${ }^{2}$ All-Russian Plant Quarantine Centre, Moscow, Russian Federation \\ ${ }^{3}$ Semnan University, Semnan, Iran \\ ${ }^{4}$ Tarbiat Modares University, Tehran, Iran \\ *Corresponding author: niloofarmahmoodi@ymail.com
}

\begin{abstract}
A technique was developed for the identification of Ditylenchus destructor nematode belonging to the Ditylenchus genus, based on the use of different primers for polymerase chain reaction (PCR). Two universal ribosomal primers were amplified to the internal transcribed spacer region ITS-rDNA. The sequencing of PCR products confirmed the polymorphism between species. The primers were sensitive to generate a particular band of the correct size (300bp) from the DNA template of a single, separate $D$. destructor stage of development. Screening populations of $D$. destructor from Iran and the Russian Federation have tested the reliability of the primers, and the expected size of the band was produced for all test populations. Ditylenchus destructor closely related species have also been tested and no specific band was amplified. Such results showed that the primers currently developed are useful for quantifying the $D$. destructor density in potato tuber.
\end{abstract}

Keywords: Potato nematode, ITS-rDNA, Ditylenchus destructor, Primer design

Acknowledgment. Funding: The research has been conducted with the support of the RUDN University Program «5-100».

\section{Article history:}

Received: 12 March 2020. Accepted: 10 April 2020

\section{For citation:}

Mahmoudi N, Nejad DK, Shayanmehr F. A new primer set for amplification of ITS-rDNA in Ditylenchus destructor. RUDN Journal of Agronomy and Animal Industries. 2020; 15(2):150 -158. doi: 10.22363/2312797X-2020-15-2-150-158

\section{Introduction}

Since the advent of polymerase chain reaction (PCR) and a large amount of genetic data produced with DNA sequencing, molecular-based detection tools have been widely developed and successfully used for plant parasite nematodes diagnosis. Molecular detection

(c) Mahmoudi N., Nejad D.K., Shayanmehr F., 2020

This work is licensed under a Creative Commons Attribution 4.0 International License https://creativecommons.org/licenses/by/4.0/1 
tools have the following advantages compared to other approaches, (i) can be used in a high throughput manner, (ii) DNA information can be easily acquired with a large number of databases and sequencing information, (iii) inexpensive, fast and accurate, (iv) DNA markers are independent of phenotypic variation and nematode developmental stage [1]. DNA-based detection tools make excellent nematode diagnostic methods because they are simple, accurate and quick [2,3] and can be used with a wide variety of sample types, including host tissue, eggs, egg masses, soil extracts and fixed samples [4]. The sequences contain readily detectable genetic markers in the form of tandem repeats used to create phylogenetic trees [5] for the evaluation and diagnosis of genetically related populations [6]. Because nematodes species descriptions have historically been focused on the idea of morphological or typological organisms, molecular techniques have recently shown that many assumed monospecific species are siblings or cryptic species, genetically distinct but shared common morphological diagnostic characteristics [7-9]. [10, 11] and [12] used and recommended the specific primers to identify $D$. destructor rDNA ITS regions have also been reported to be used successfully for phylogenetic analysis [11-14]. Nonetheless, the definition of nematode species has been debated recently, indicating that species delimitation should be based primarily on an amalgamation of polyphasic taxonomy concepts, which assembles and assimilates all available data and information (phenotypic, genotypic and phylogenetic) used to delimit taxa at all levels $[8,9,15]$. The main accessible strategy that possibly can separate among the haplotypes is those of $[12,16,17] D$. gigas have been developed [12, 13, 18, 19]. This method is suitable for the identification of species in monospecific samples but cannot be used if the sample contains more than one nematode species using species-specific SCAR or ITS-rRNA primers [11, 12, 20_22]. This study aimed to develop a PCR species-specific primers with sensitivity and reliability based on the sequence analysis for the molecular identification of $D$. destructor from other Ditylenchus species.

\section{Materials and methods}

DNA extraction. Nematodes were extracted from potatoes (Solanum tuberosum L.) collected from different regions in the Russian Federation and Iran. Several nematode specimens from the population were put into a drop of water and cut by a scalpel under a camera-equipped ZEISS Axioskop50® microscope. DNA extraction from the material under this research was laid out by treating the specimens with Proteinase $\mathrm{K}$ that was followed by removing proteins with no extraction with organic solvents. For this purpose, a DNA-Ekstran-2 set No EX-511-100 (Synthol, Moscow) was used.

PCR with Species-specific primers. The first PCR amplification mixture (final volume $25 \mu \mathrm{l}$ ) was prepared as follows in a PCR tube (Table 1).

PCR reaction mixture composition

\begin{tabular}{|c|c|}
\hline Reagents & Volume $\mu \mathrm{l}$ \\
\hline Master Mix & $5 \mu \mathrm{l}$ \\
\hline Primer DITdesR & $0.6 \mu \mathrm{l}$ \\
\hline Primer DITuniF & $0.6 \mu \mathrm{l}$ \\
\hline H20 & $13.8 \mu \mathrm{l}$ \\
\hline DNA & $5 \mu \mathrm{l}$ \\
\hline Total & $25 \mu \mathrm{l}$ \\
\hline
\end{tabular}


The primer DITdesR and DITuniF were used for PCR Species-specific amplification. The contents were mixed gently by overtaxing. The reaction was performed in a thermal cycler, which involved the following stepwise procedure: denaturation of the template at $95{ }^{\circ} \mathrm{C}$ for 3 minutes, annealing at $95{ }^{\circ} \mathrm{C}$ for 35 seconds followed by extension at $63.5^{\circ} \mathrm{C}$ for 30 seconds, $72{ }^{\circ} \mathrm{C}, 30$ seconds and 5 minutes at $72{ }^{\circ} \mathrm{C}$ for 35 cycles. Negative control was included with each set of amplification. Then, The PCR products were subsequently partitioned according to their size on $1 \%$ agarose gel electrophoresis and visualized by Gel documentation or purified for sequencing.

Sequencing and Phylogenetic analysis. The amplified PCR product obtained after purification by Thermo Scientific Gene JET Gel Extraction Kit was sequenced by Sanger's dideoxy cycle by Genetic Analyzer AB-3500 (Applied Biosystems, USA). Primitive comparison of sequencing results with the GeneBank genetic sequence database was done by the NCBI BLAST web site (http://www.ncbi.nlm.nih.gov/BLAST). The results are presented in percentage values, the DNA sequence available in the GeneBank homologous to those examined were analyzed along with the newly sequenced one.

Design of Species-specific Primers. The ITS sequences of $D$. destructor including MN122076, MN307126, MN307128, MN493767, MN658597, MN658599, MN658637, MN658638 and D. dipsaci: MG676655, MG676656, MG676656, D. gigas: KJ653270, KJ653267 which were retrieved from NCBI and were used for the design of specific primers (Table 2). The specific forward and reverse primers were designed from the ITS regions using Primer Premier DITdesR and DITuniF to generate an expected fragment of about 126 bp in length and verified using BLAST (http://www.ncbi.nlm.nih.gov/blast) to exclude nonspecific reactions with other closely related species.

Sequence information from GenBank for designing species-specific primers

\begin{tabular}{|c|c|c|}
\hline Accession Number & Species & Country \\
\hline GQ469492 & Ditylenchus destructor \\
\hline GQ469491 & Ditylenchus destructor & Czech Republic \\
\hline KJ653270 & Ditylenchus gigas & Iran \\
\hline KJ653267 & Ditylenchus gigas \\
\hline MG676655 & Ditylenchus dipsaci & Japan \\
\hline MG676656 & Ditylenchus dipsaci & Japan \\
\hline MG676657 & Ditylenchus dipsaci & Japan \\
\hline
\end{tabular}

\section{Results and discussion}

Ditylenchus destructor DNA sequence analysis. The sequenced ITS-rRNA gene, deposited in NCBI GenBank under accession numbers; MN122076, MN307126, MN307128, MN493767, MN658597, MN658599, MN658637, MN658638 (Table 3) are 1013 bp, 1160 bp, and 1108 bp, 637bp, 553bp, 501bp, 624bp long, respectively. BLAST search at NCBI revealed that all molecular markers of $D$. destructor from Russia Federation 
and Iran, newly obtained in this study, matched with the corresponding sequences of $D$. destructor present in the database (Table 4). The sequence analysis revealed sequence variability between different geographical populations of $D$. destructor isolated from different host plants.

Submitted Sequences in NCBI GenBank

\begin{tabular}{|c|c|}
\hline Region & Accession Number \\
\hline Moscow region & MN122076 \\
\hline Hamedan region & MN307126 \\
\hline Hamedan region & MN307128 \\
\hline Hamedan region & MN493767 \\
\hline Briansk region & MN658597 \\
\hline Briansk region & MN658599 \\
\hline Nizhny Novgorod region & MN658637 \\
\hline Nizhny Novgorod region & MN658638 \\
\hline
\end{tabular}

Reference sequences of $D$. destructor used in the phylogenetic analysis (http://www.ncbi.nlm.nih.gov)

\begin{tabular}{|c|c|c|}
\hline Accession Number of D. destructor & Country & Host Plant \\
\hline MH992393 & China & Potato \\
\hline EU400636 & China & Sweet potato \\
\hline EU400627 & South Korea & Sweet potato \\
\hline EF208213 & China & Potato \\
\hline HQ235698 & Iran & Potato \\
\hline FJ707365 & Czech Republic & Potato \\
\hline MG673926 & China & Carrot \\
\hline EU400638 & China & Sweet potato \\
\hline MG675235 & China & Carrot \\
\hline EU400643 & China & Sweet potato \\
\hline KY435979 & China & Carrot \\
\hline EU400639 & China & Sweet potato \\
\hline GQ469490 & USA & Potato \\
\hline JX162205 & Canada & Garlic \\
\hline DQ328727 & Russia & Potato \\
\hline JN166693 & Iran & Potato \\
\hline MK979365 & China & Potato \\
\hline MG673926 & China & Carrot \\
\hline KX766417 & China & Potato \\
\hline LC030371 & Japan & Potato \\
\hline GQ469491 & Czech Republic & Potato \\
\hline DQ471335 & China & Potato \\
\hline
\end{tabular}

Design of Species-specific Primers. A first primer named dsn.1 (Table 5) was designed to have some nucleotides mismatches observed when comparing D. destructor, D. dipsaci, and D. gigas (Fig 1, 2). At present, a set of species-specific primers for $D$. destructor were developed based on the sequence differences in the rDNA-ITS region of $D$. destructor. The PCR amplification by the species-specific primers demonstrated that it could amplify 
a single, stable and clear band for a single adult and different geographical populations of $D$. destructor. The specificity and reliability of the primers were also demonstrated in vitro conditions. Given the specificity, sensitivity, and reliability of the primers for $D$. destructor, the diagnostic primers could provide a rapid and reliable molecular marker for identification or detection of $D$. destructor. Typically, testing diagnostic primers usually need more samples with similar morphological characteristics and more geographically disparate locations [23]. Possibly, the species-specific primers designed in the present work may cross-react with other species in the genus of Ditylenchus and mismatches at the primer-binding site to produce the same specific band.

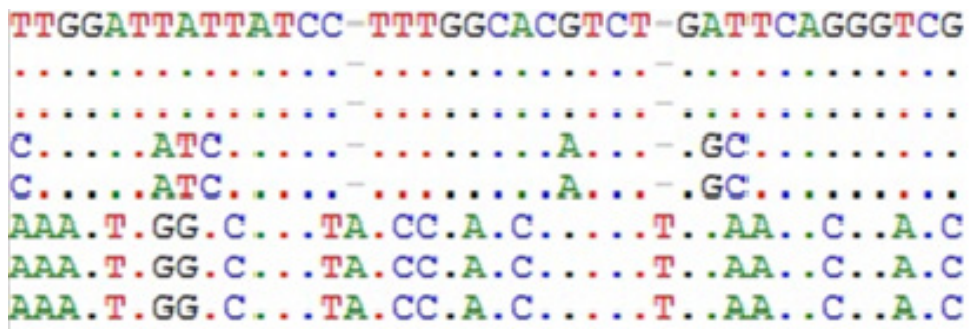

Fig 1. Multi-alignment generated of the rDNA-ITS sequences of $D$. destructor and other Ditylenchus species from GenBank used to develop the species-specific forward primer

\section{AGCACGTGTTTCTTGTGCAGCCTCTTGGCCAATGTTGA}

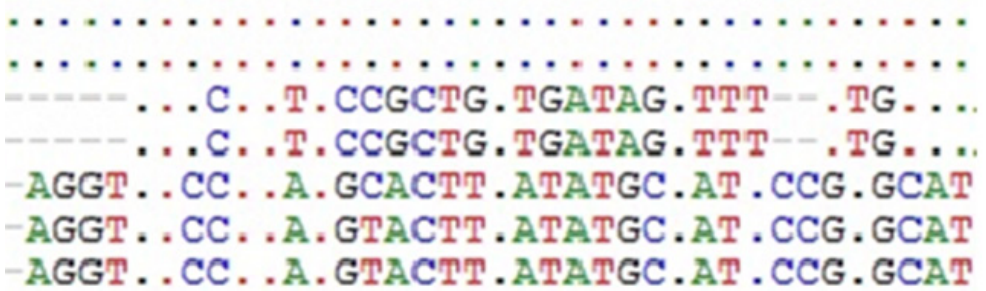

Fig 2. Multi-alignment generated of the rDNA-ITS sequences of $D$. destructor and other Ditylenchus species from GenBank used to develop the species-specific reverse primer

Table 5

Primer design for $D$. destructor

\begin{tabular}{|c|c|c|c|c|c|c|c|}
\hline Primer.dsn.1 & Sequence $\left(5^{\prime}\right.$ ' $^{\prime}$ ') & $\begin{array}{c}\text { Template } \\
\text { strand }\end{array}$ & Length & Start & Stop & Tm & GC\% \\
\hline Forward primer & TTGGCACGTCTGATTCAGGG & Plus & 20 & 193 & 212 & 60.32 & 55.00 \\
\hline Reverse primer & GTCAACATTGGCCAAGAGGC & Minus & 20 & 318 & 299 & 59.76 & 55.00 \\
\hline Product length & \multicolumn{7}{|c|}{126} \\
\hline
\end{tabular}

Table 6

Primer design for $D$. destructor by NCBI Primer-Blast

\begin{tabular}{|c|c|c|c|c|c|c|c|}
\hline Primer.dsn.2 & Sequence $\left(5^{\prime}>\mathbf{3}^{\prime}\right)$ & $\begin{array}{c}\text { Template } \\
\text { strand }\end{array}$ & Length & Start & Stop & Tm & GC\% \\
\hline Forward primer & TTTCGAATGCACATTGCGCC & Plus & 20 & 157 & 176 & 60.73 & 50.00 \\
\hline Reverse primer & CTAGGCCAAAGAGACAGCGG & Minus & 20 & 281 & 262 & 60.46 & 60.00 \\
\hline Product length & \multicolumn{7}{|c|}{125} \\
\hline
\end{tabular}


Test of Species-specific Primers. To evaluate the sensitivity of the species-specific primers, the PCR amplified products for different numbers of $D$. destructor amplified using the primers (dsn.1 and dsn.2) were shown in (Fig 3). A single band with a length of 300 bp was obtained from DNA templates extracted $D$. destructor. The method proved suitable for $D$. destructor sensitive identification of DNA samples. The specificity and reliability of the specific primers were confirmed by yielding the expected fragment sizes (300 bp) for all the populations of $D$. destructor and no products were detected for the tested of the species D. dipsaci and D. gigas (Fig 4).

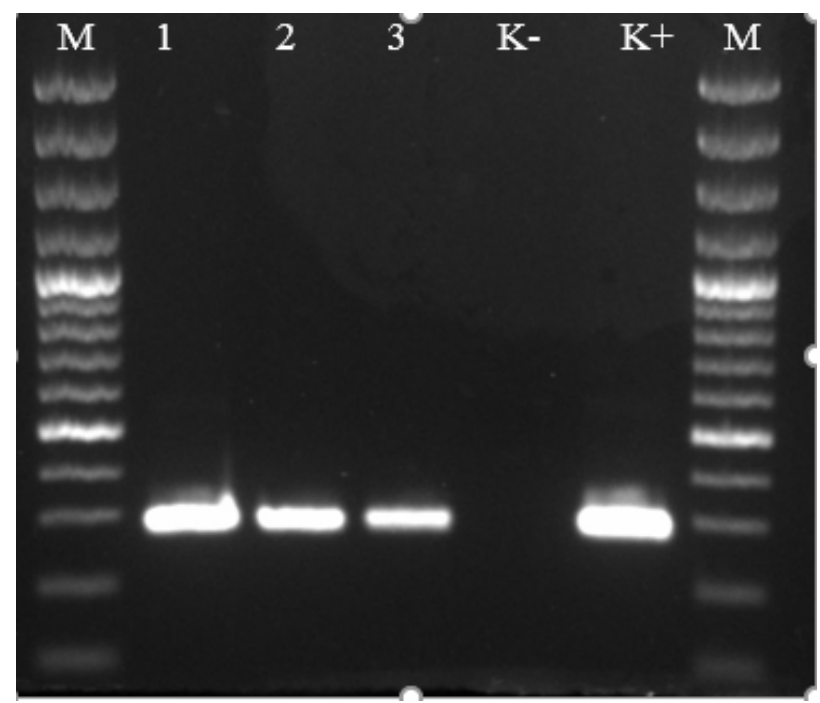

Fig 3. Gel with amplification products obtained in PCR with species-specific primer from the $D$. destructor population. Lanes: $M=100$ bp DNA ladder; $K+=$ Positive control with $D$. destructor DNA; $\mathrm{K}-=$ control without DNA

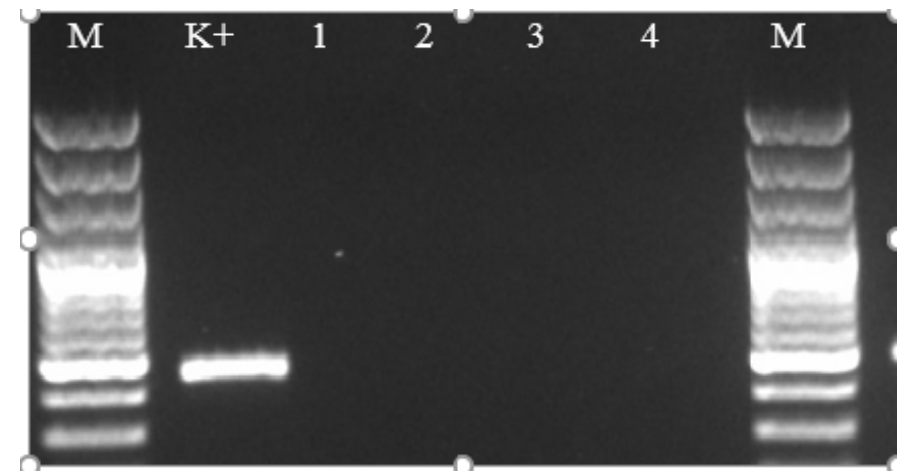

Fig 4. Gel with amplification products obtained in PCR with species-specific primer. Lanes: $M=100$ bp DNA ladder; K+=Positive control with $D$. destructor DNA; 1,2 = with $D$. dipsaci DNA; 3, 4 = with D. gigas DNA

\section{Conclusions}

In this study, a set of species-specific primers (named dsn.1/dsn.2) was designed firstly for molecular identification of $D$. destructor based on the sequence analysis of rDNA-ITS. The specificity, sensitivity, and reliability of the primers were repeatedly 
demonstrated. Therefore, the developed specific primers should be a rapid and accurate molecular protocol for the diagnosis of $D$. destructor and also be fundamental for effective management of the nematode.

\section{References}

1. Abebe E, Mekete T, Thomas WK. A critique of current methods in nematode taxonomy. African Journal of Biotechnology. 2011; 10(3):312-323.

2. Blok VC, Powers TO. Biochemical and molecular identification. In: Perry RN, Moens M, Star J. (eds.) Root Knot Nematodes. 1st ed. London: CABI International; 2009. p. 98-112.

3. Castagnone-Sereno P. Meloidogyne enterolobii (=M. mayaguensis): profile of an emerging, highly pathogenic, root-knot nematode species. Nematology. 2012; 14(2):133—138. doi: 10.1163/156854111X601650

4. Nega A. Review on nematode molecular diagnostics: From bands to barcode. Journal of Biology, Agriculture and Healthcare. 2014; 4(27):129-153.

5. Jeszke A, Budziszewska M, Dobosz R, Stachowiak A, Protasewicz D, Wieczorek P, et al. Comparative and Phylogenetic Study of the Ditylenchus dipsaci, Ditylenchus destructor and Ditylenchus gigas Populations Occurring in Poland. Journal of Phytopathology. 2014; 162(1):61—67. doi.org/10.1111/jph.12161

6. Nowaczyk K, Obrepalska-Steplowska A, Gawlak M, Throne JE, Olejarski P, Nawrot J. Molecular techniques for detection of Tribolium confusum infestations in stored products. J Econ Entomol. 2009; 102(4):1691-1695. doi: 10.1603/029.102.0437

7. Subbotin S, Maafi ZT, Moens M. Molecular identification of cyst-forming nematodes (Heteroderidae) from Iran and a phylogeny based on ITS-rDNA sequences. Nematology. 2003; 5(1):99-111. doi: $10.1163 / 156854102765216731$

8. Vovlas N, Troccoli A, Palomares-Rius JE, De Luca F, Cantalapiedra-Navarrete C, Liebanas G, et al. A new stem nematode, Ditylenchus oncogenus n.sp. (Nematoda: Tylenchida), parasitizing sowthistle from Adriatic coast dunes in southern Italy. Journal of Helminthology. 2016; 90(2):152 - 165. doi: 10.1017/S0022149X14000947

9. Gutierrez-Gutierrez C, Palomares-Rius JE, Cantalapiedra-Navarrete C, Landa BB, Esmenjaud D, Castillo P. Molecular analysis and comparative morphology to resolve a complex of cryptic Xiphinema species. Zoologica Scripta. 2010; 39(5):483-498. doi: 10.1111/j.1463-6409.2010.00437.x

10. Vrain TC, Wakarchuk DA, Levesque AC, Hamilton IR. Intraspecific rDAN restriction fragment length polymorphism in the Xiphinema americanum group. Fundam Appl Nematol. 1992; 15(6):563—573.

11. Marek M, Zouhar M, Douda O, Mazakova J, Rysanek P. Bioinformatics-assisted characterization of the ITS1 - 5.8S-ITS2 segments of nuclear rRNA gene clusters, and its exploitation in molecular diagnostics of European crop parasitic nematodes of the genus Ditylenchus. Plant Pathology. 2010; 59(5):931-943. doi: 10.1111/j.1365-3059.2010.02322.x

12. Subbotin SA, Madani M, Krall E, Sturhan D, Moens MJP. Molecular diagnostics, taxonomy, and phylogeny of the stem nematode Ditylenchus dipsaci species complex based on the sequences of the internal transcribed spacer-rDNA. Nematology. 2005; 95(11):1308-1315. doi: 10.1094/PHYTO-95-1308

13. Vovlas N, Troccoli A, Palomares-Rius JE, De Luca F, Liébanas G, Landa BB, et al. Ditylenchus gigas n. sp. parasitizing broad bean: a new stem nematode singled out from the Ditylenchus dipsaci species complex using a polyphasic approach with molecular phylogeny. Plant Pathol. 2011; 60(4):762 — 775. doi: 10.1111/j.13653059.2011.02430.x

14. Pethybridge SJ, Gorny A, Hoogland T, Jones L, Hay F, Smart C, et al. Identification and characterization of Ditylenchus spp. populations from garlic in New York State, USA. Tropical Plant Pathology. 2016; 41(3):193_ 197. doi: 10.1007/s40858-016-0083-7

15. Subbotin SA, Moens M. Molecular taxonomy and phylogeny. In: Perry R, Moens M. (eds.) Plant Nematology. Wallingford, UK: CABI Publishing; 2006; p. 33-58.

16. Fand BB, Nagrare VS, Deshmukh V, Naikwadi BV, Gokte-Narkhedkar N, Waghmare VN. A simple and low-cost laboratory rearing technique for pink bollworm, Pectinophora gossypiella (Suanders) (Lepidoptera: Gelechidae) using detached green bolls of cotton. Phytoparasitica. 2019; 48:25—33. doi: 10.1007/s12600_ 019-00779-2

17. Liu B, Mei Y, Zheng J. Species-specific detection of interpopulations of Ditylenchus destructor. J Zhejiang Univ. 2007; 33:490-496.

18. Wendt KR, Vrain TC, Webster JM. Separation of three species of Ditylenchus and some host races of $D$. dipsaci by restriction fragment length polymorphism. Journal of Nematology. 1993; 25(4):555—563. 
19. Chizhov VN, Borisov BA, Subbotin SA. A new stem nematode, Ditylenchus weischeri n. sp. (Nematoda: Tylenchida), a parasite of Cirsium arvense (L.) Scop. in the Central Region of the Non-Chernozem Zone of Russia. Russian Journal of Nematology. 2010; 18(2):95-102.

20. Esquibet M, Grenier E, Plantard O, Abbad Andaloussi F, Caubel G. DNA polymorphism in the stem nematode Ditylenchus dipsaci: Development of diagnostic markers for normal and giant races. Genome. 2003; 46(6):1077-1083. doi: 10.1139/g03-72

21. Kerkoud M, Esquibet M, Plantard O, Avrillon M, Guimier C, Franck M. Identification of Ditylenchus species associated with Fabaceae seeds based on a specific polymerase chain reaction of ribosomal DNA-ITS regions. Eur J Plant Pathol. 2007; 118:323-332. doi: 10.1007/s10658-006-9092-6

22. Zouhar M, Marek M, Douda O, Mazakova J, Rysanek P. Conversion of sequence-characterized amplified region (SCAR) bands into high-throughput DNA markers based on RAPD technique for detection of the stem nematode Ditylenchus dipsaci in crucial plant hosts. Plant Soil Environ. 2007; 53(3):97-104.

23. Oliveira RD, Santin ÂM, Seni DJ, Dietrich A, Salazar LA, Subbotin SA, et al. Ditylenchus gallaeformans n. sp. (Tylenchida: Anguinidae) — a neotropical nematode with biocontrol potential against weedy Melastomataceae. Nematology. 2013; 15(2):179—19.

\title{
About authors:
}

Mahmoudi Niloufar — PhD candidate, Department of Agro-Biotechnology, Agrarian and Technological Institute, Peoples’ Friendship University of Russia, 8, Miklukho-Maklaya st., Moscow, 117198, Russian Federation; Researcher, Russian Plant Quarantine Center (VNIIKR), 32, Pogranichnaya st., vill. Bykovo, Ramensky district, Moscow region, 140150, Russian Federation; e-mail: niloofarmahmoodi@ymail.com

Nejad Davoud Kartooli — Assistant Professor of Forestry, Faculty of Desert Studies, Semnan University, Mowlawi Boulevard, Motahari Square, 35196-45399, Semnan, Iran, e-mail: Kartooli58@gmail.com; ORCID 0000-00020852-6635

Shayanmehr Fatemeh — PhD in Forestry, Natural Resources Faculty, Tarbiat Modares University, 14155-4838, Tehran, Iran

\section{Новый набор праймеров для специфичной амплификации ITS-локусов рДНК Ditylenchus destructor}

\author{
Н. Махмуди ${ }^{1,2 *}$, Д.К. Неджад ${ }^{3}$, Ф. Шаянмер ${ }^{4}$
}

${ }^{1}$ Российский университет дружбы народов, г. Москва, Российская Федерация ${ }^{2}$ Всероссийский центр карантина растений, Московская область, Российская Федерация

${ }^{3}$ Семнанский университет, г. Семнан, Иран

${ }^{4}$ Университет Тарбиат Модарес, г. Тегеран, Иран

*niloofarmahmoodi@ymail.com

\begin{abstract}
Аннотация. Разработана методика идентификации нематоды Ditylenchus destructor, основанная на использовании различных праймеров для проведения полимеразной цепной реакции (ПЦР). Два универсальных рибосомных праймера были амплифицированы во внутренней транскрибируемой области спейсера ITS-рДНК. Секвенирование продуктов ПЦР подтвердило полиморфизм между видами. Праймеры достаточно чувствительны, чтобы генерировать определенную полосу правильного размера (300 п.н.) из ДНК-матрицы определенной стадии развития D. destructor. Скринингом популяций D. destructor из Ирана и Российской Федерации проверена надежность праймеров, и ожидаемый размер полосы был получен для всех тестируемых популяций. Близкородственные виды Ditylenchus destructor также были протестированы, и специфической имплифицированной полосы не было выявлено. Результаты исследований показали, что данные разработанные праймеры могут использоваться для количественной оценки плотности D. destructor в клубнях картофеля.
\end{abstract}

Ключевые слова: картофельная нематода, ITS-рДНК, Ditylenchus destructor, праймеры 
Финансирование. Благодарности: Исследование проведено при финансовой поддержке Программы РУДН «5-100».

\section{История статьи:}

Поступила в редакцию: 12 марта 2020 г. Принята к публикации: 10 апреля 2020 г.

\section{Для цитирования:}

Mahmoudi N., Nejad D.K., Shayanmehr F. A new primer set for amplification of ITS-rDNA in Ditylenchus destructor // Вестник Российского университета дружбы народов. Серия: Агрономия и животноводство. 2020. T. 15. № 2. C.150-158. doi: 10.22363/2312-797X-2020-15-2-150-158

\section{Об авторах:}

Махмуди Нилоуфар - аспирант агробиотехнологического департамента, Аграрно-технологический институт, Российский университет дружбы народов, Российская Федерация, г. Москва, 117198, ул. Миклухо-Маклая, д. 8; научный сотрудник, Всероссийский центр карантина растений (ВНИИКР), Российская Федерация, Московская область, 140150, Раменский район, п. Быково, ул. Пограничная, д. 32; e-mail: niloofarmahmoodi@ymail.com

Неджад Давуд Картули - доцент кафедры лесоводства, факультет исследований пустынь, Университет Семнан, Иран, 35196-45399, Семнан, площадь Мотахари, бульвар Молави; e-mail: Kartooli58@gmail. com; ORCID 0000-0002-0852-6635

Шаянмер Фатиме — кандидат наук, факультет природных ресурсов, Университет Тарбиат Модарес, 14155-4838, Иран, Тегеран 